\title{
A Simple Independent Predictor of in-Hospital and Long-Term Outcomes in Patients with STEMI: Plateletcrit
}

\section{STEMI Hastalarında Hastane İçi ve Uzun Dönem Olaylar için Basit ve Bağımsız Bir Prediktör: Plateletkrit}

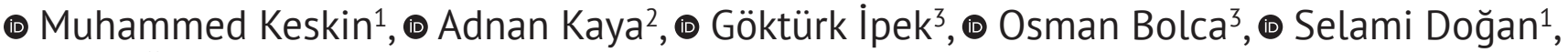 \\ ๑) Fatih Özçelik ${ }^{4}, \bullet$ Ahmet L. Orhan ${ }^{1}$ \\ ${ }^{1}$ University of Health Sciences Turkey, İstanbul Sultan 2. Abdülhamid Han Training and Research Hospital, Department of Cardiology, Istanbul, Turkey \\ ${ }^{2}$ Düzce University Faculty of Medicine, Department of Cardiology, Düzce, Turkey \\ ${ }^{3}$ Dr. Siyami Ersek Training and Research Hospital, Clinic of Cardiology, İstanbul, Turkey \\ ${ }^{4}$ University of Health Sciences Turkey, İstanbul Sultan 2. Abdülhamid Han Training and Research Hospital, Clinic of Biochemistry, Istanbul, Turkey
}

Background: Platelet mass, namely plateletcrit (PCT), is the total platelet mass which is calculated by multiplying platelet count with mean platelet volume. There are several studies revealing that higher PCT is associated with higher mortality in patients with myocardial infarction. We aimed to investigate the association of high PCT levels and in -hospital and long-term outcomes of ST-segment elevation myocardial infarction (STEMI) in a high-volume center.

Materials and Methods: A total of 2.415 patients were eligible to the study. The study population was divided into three tertiles according to the PCT values starting from the lowest to highest level (T1,T2,T3). In-hospital and long-term outcomes were compared between these tertiles.

Results: In-hospital acute kidney injury, recurrent myocardial infarction, target lesion revascularization, stent thrombosis, cardiogenic shock and all-cause mortality rates were significantly higher in T3 compared to other tertiles. Besides, the rate of long-term all-cause mortality was higher in T3 than in the other tertiles. In the multivariable regression analysis, high PCT was found as an independent predictor for mortality.

Conclusion: The current study demonstrated the higher in-hospital and long-term unfavorable outcomes in patients with STEMI, who had a high PCT.

Keywords: Myocardial infarction, plateletcrit, mortality

Amaç: Plateletkrit (PCT) olarak bilinen total platelet kütlesi platelet sayısı ile ortalama platelet hacminin çarpılması ile hesaplanır ve bazı akut miyokart enfarktüsü çalışmalarında yüksek PCT değerleri artmış mortalite ile ilişkilendirilmiştir. Biz bu çalışmamızda yüksek hasta hacimli bir merkezdeki ST-segment yükselmeli miyokart enfarktüsü (STYME) hastalarındaki PCT'nin hastane içi ve uzun dönem mortalite ile ilişkisini araştırdık.

Gereç ve Yöntemler: Toplam 2,415 hasta çalışma için uygun bulundu. PCT değerlerine göre hastalar en düşükten en yükseğe doğru sıralanarak 3 tertile ayrıldı (T1,T2,T3). Hastane içi ve uzun dönem sağkalımlar bu gruplar arasında karşılaştırıldı.

Bulgular: Akut böbrek hasarı, tekrarlayan miyokart enfarktüsü, hedef damar revaskülarizasyonu, stent trombozu, kardiyojenik şok ve tüm nedenli ölüm sıklığı diğer gruplara kıyasla T3’te daha yüksekti. Uzun dönemdeki tüm nedenli ölümler de aynı şekilde diğer gruplara kıyasla T3’te daha yüksekti. Çoklu regresyon analizinde yüksek PCT düzeyi mortalite ile bağımsız olarak ilişkili bulundu. Sonuç: Mevcut çalışmada STYME hastalarında yüksek PCT değerleri artmış hastane içi ve uzun dönem olumsuz olaylarla ilişkili bulundu.

Anahtar Kelimeler: Miyokart enfarktüsü, plateletkrit, mortalite

Address for Correspondence: Muhammed Keskin, University of Health Sciences Turkey, İstanbul Sultan 2. Abdülhamid Han Training and Research Hospital,

Department of Cardiology, İstanbul, Turkey

Phone: +90 2165422020 E-mail: drmuhammedkeskin@gmail.com ORCID ID: orcid.org/0000-0002-4938-0097

Received: 25.07.2020 Accepted: 21.09.2020 


\section{Introduction}

Platelets, like other hematopoietic cells, are produced in the bone marrow and are so small that they even miss a nucleus (1). Platelet activation plays a key role for coronary thrombosis and occlusion after coronary plaque rupture that is defined as Acute Coronary syndromes (ACS). ST segment elevation myocardial infarction (STEMI) is the most severe form of the ACS, which is characterized by an abrupt vessel occlusion. Myocardial ischemia and subsequent necrosis follow vessel occlusion if left untreated (2).

Platelet volume, which varies from 7 to 13 femtoliter in normal healthy individuals (3), is a marker of platelet activation and is measured using the mean platelet volume (MPV) $(4,5)$. Platelet mass, namely plateletcrit (PCT), is the total platelet mass which is calculated by multiplying platelet count with MPV $\left(P C T=\right.$ platelet count $\left.\times M P V / 10^{7}\right)(6)$ and is reported routinely in the complete blood count report. Since larger platelets are enzymatically more active than the smaller ones (7), the association of MPV and platelet count with high thrombotic states like non-STEMI have already been studied (4). Besides, there are studies showing higher PCT and mortality association among STEMI patients $(8,9)$. However, there is a lack of conclusive literature about the association between PCT and STEMI patients that undergone primary percutaneous coronary intervention $(\mathrm{PPCl})$ yet. We aimed to investigate the association of high PCT and in-hospital and long-term outcomes of STEMI in a high-volume center.

\section{Material and Methods}

\section{Study Population}

A total of 2.838 consecutive patients with STEMI, who were admitted to a high-volume tertiary cardiovascular hospital (>2.500 PCls/year) from January 2012 to February 2014, were retrospectively investigated. The study was approved by the local ethics committee $(28.08 .2020,20 / 312)$, and due to the retrospective nature, there was no opportunity to obtain written informed consent from the patients. The data were anonymized by removing personally identifiable information.

STEMI diagnosis was made according to the following criteria: (1) typical chest pain lasting for $>30$ minutes and (2) STsegment elevation in at least 2 contiguous leads with the following cutoff points: at least $0.2 \mathrm{mV}$ in men or at least 0.15 $\mathrm{mV}$ in women in leads V2-V3 and/or at least $0.1 \mathrm{mV}$ in the other leads or a definite/probable new left bundle branch block in electrocardiogram (ECG) later confirmed by creatine kinase (CK) and CK-myocardial band (CK-MB) isoenzyme increases and/or troponin increases (10).

We excluded patients (I) without appropriate STEMI diagnosis ( $\mathrm{N}=105)$, (II) without PCT values at admission ( $\mathrm{N}=73$ ), (III) without data about previous medical treatment ( $N=56)$, (IV) with acute or chronic hepatic failure (N=33), (V) with chronic obstructive pulmonary disease $(\mathrm{N}=38),(\mathrm{VI})$ with peripheral and cerebral arterial disease ( $\mathrm{N}=21)$, (VII) with inflammatory diseases, acute or chronic infectious disease ( $\mathrm{N}=41)$, (VII) with autoimmune diseases, malignancies $(\mathrm{N}=9), \quad(\mathrm{IX})$ with hypothyroidism, hyperthyroidism ( $N=11),(X)$ with cardiomyopathies and heart failure $(\mathrm{N}=17)$, and $(\mathrm{XI})$ with severe valvular disease $(\mathrm{N}=19)$ (Figure 1). After the exclusion of the patients according the criteria above, a total of 2.415 patients were eligible to the study. The study population was divided into tertiles according to the PCT values [T1 $(\mathrm{N}=805), \mathrm{T} 2(\mathrm{~N}=805), \mathrm{T} 3(\mathrm{~N}=805)]$.

\section{Data Collection}

Demographic information and the clinical history of risk factors were obtained from medical data. Blood samples were obtained as soon as the STEMI diagnosis was made [in the emergency room (ER)]. Platelet count and MPV were measured by Coulter LH 780 Hematology Analyzer (Beckman Coulter Ireland Inc, Galway, Ireland). The PCTs were calculated according to the formula $(P C T=$ platelet count $\times$ MPV/10,000). A 12-lead ECG was obtained for each patient as soon as the patent was seen in ER. Glomerular filtration rate (GFR) was estimated according to Cockcroft-Gault formula (11), and a transthoracic echocardiogram was performed using a system $\mathrm{V}$ (Vingmed; GE, Horten, Norway) with a $2.5-\mathrm{mHz}$ phased array transducer. The left ventricular ejection fraction (LVEF) was measured with the modified Simpson's rule (12).

\section{Coronary Angiography and PPCI}

As soon as the diagnosis of STEMI was made, a loading dose of $300 \mathrm{mg}$ of chewable acetylsalicylic acid and a P2Y12

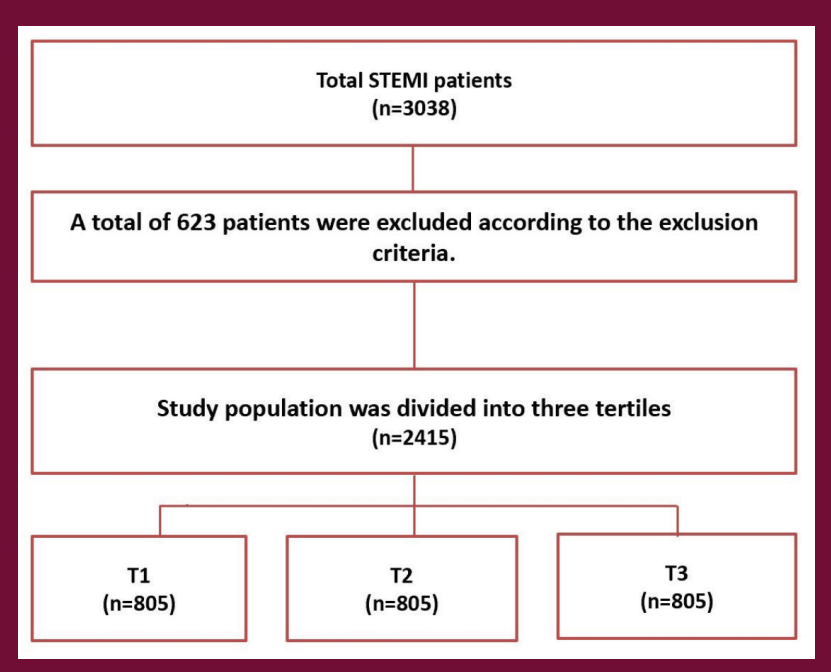

Figure 1. Study flow chart

STEMI: Segment elevation myocardial infarction 
inhibitor were administered. All interventions were performed via the insertion of a $6 \mathrm{~F}$ femoral sheath (Super Sheath; Boston Scientific, Natick, Massachusetts) to either the right or left common femoral artery. An intravenous bolus (100 $\mathrm{IU} / \mathrm{kg}$ ) of unfractionated heparin was administered through venous access in patients without enoxaparin administration previously. An activated clotting time of $\geqslant 200$ seconds was aimed at prolonged interventions with more unfractionated heparin addition. Patients with initial administration of $1 \mathrm{mg} / \mathrm{kg}$ of enoxaparin within 8 hours of the intervention were followed without an additional enoxaparin booster, while $0.3 \mathrm{mg} / \mathrm{kg}$ of additional enoxaparin booster was administered to patients with 8 to 12 hours of enoxaparin administration. Predilation with a balloon angioplasty was performed whenever needed before stent deployment. Thrombus aspiration catheters were used whenever needed. The interventional cardiologists (ICS) decided the type of coronary stent according to the national and international guidelines and recommendations. Glycoprotein Ilb/IIla inhibitor usage was also up to the ICs preference. Intracoronary administration of adenosine, nitrates, and calcium channel blockers was also allowed according to the preference of the IC in cases of NR during PPCI.

\section{Definitions}

Hypertension (HT) was defined as having a blood pressure $\geqslant 140 / 90 \mathrm{mmHg}$ at admission and/or being on anti-hypertensive drugs. Diabetes mellitus (DM) was defined as having (I) a random plasma glucose level $\geqslant 200 \mathrm{mg} / \mathrm{dL}$, (II) a fasting plasma glucose level $\geqslant 126 \mathrm{mg} / \mathrm{dL}$, (III) an HA1C $\geqslant 6.5 \%$ and/or being on antidiabetic drugs. Hyperlipidemia (HL) was defined as having a total cholesterol level $\geqslant 240 \mathrm{mg} / \mathrm{dL}$, a serum triglyceride $\geqslant 200$ $\mathrm{mg} / \mathrm{dL}$, low-density lipoprotein cholesterol $\geqslant 130 \mathrm{mg} / \mathrm{dL}$ and/ or being on anti-hyperlipidemic drugs. Chronic kidney disease (CKD) was defined as having an eGFR $<60 \mathrm{~mL} / \mathrm{min} / 1.73 \mathrm{~m}^{2}$ and/or being on hemodialysis. Door-to-balloon time was the duration from admission to balloon inflation in the infarct related artery. The no-reflow phenomenon was defined as having a TIMI blood flow $<3$ after the PPCI. In-hospital mortality was defined as death from any cause during hospitalization. Cardiogenic shock was defined as systolic pressure $<90 \mathrm{mmHg}$ or systolic pressure drop greater than or equal to $40 \mathrm{mmHg}$ for $>15$ min without new-onset arrhythmia, hypovolemia, or sepsis. Follow-up data were obtained from hospital records or by interviewing (directly or by telephone) patients, their families, or their personal physicians.

\section{Statistical Analysis}

The study population was divided into tertiles based on PCT values on admission. The Kolmogorov-Smirnov test was used for testing normality. Continuous variables with normal distributions were expressed as mean \pm standard deviation
(SD) and compared using One-Way analysis of variance. Continuous variables without normal distributions were expressed as mean \pm SD and compared using the KruskalWallis test. Categorical variables were expressed as number and percentages and the Pearson's $\chi^{2}$ or Fisher's Exact tests were used to evaluate the differences. A backward stepwise multivariate Cox regression analysis, which included variables with $p<0.1$, was performed to identify independent predictors of cardiovascular mortality. The cumulative survival curve for cardiovascular mortality was constructed using the KaplanMeier method, with the differences assessed using the logrank test. All statistical analyses were carried out using SPSS (version 20.0; IBM, Chicago, IL).

\section{Results}

Baseline characteristics and laboratory findings were showed in Table $1 . T 1$ had a mean plateletcrit of $0.156 \pm 0.02 \%$ while the T2 had $0.209 \pm 0.01 \%$ and the T3 had $0.284 \pm 0.05 \%$. The patients in T3 were older than the other tertiles $(p=<0.001)$. There were more female in T3 than in the other tertiles $(p=$ $<0.001)$. HT ( $p=0.027)$, DM $(p=0.008)$ and HL $(p=0.020)$ were also more common in T3 than in the other tertiles. Left ventricle ejection fraction was lower in T3 than in the other tertiles ( $p=<0.001$ ). The T3 had lower eGFR, higher admission glucose, higher peak CK-MB, higher white blood cell count than the other tertiles while the T2 had higher hematocrit levels than the others. There was no difference in relation of in-hospital medication.

Angiographic and procedural properties of the patients were presented in Table 2. There were no differences with regard to stent type (bare metal or drug eluting), intervention type (direct stenting, PTCA and stenting or only PTCA), number of vessels affected and TIMI blood flow after intervention.

In-hospital and long-term outcomes of the patients were presented in Table 3. Higher in-hospital MACE were observed in T3. Acute kidney injury ( $p=0.027)$, recurrent myocardial infarction $(p=<0.001)$, target lesion revascularization $(p=0.001)$, stent thrombosis $(p=0.003)$, cardiogenic shock $(p=$ $<0.001)$ and all-cause mortality $(p=<0.001)$ were altogether more common in T3 than the other tertiles. Out of hospital course was also unfavorable for T3. All-cause mortality in long term was higher in T3 than in the other tertiles $(p=<0.001)$. The Kaplan-Meier cumulative survival curve was shown in Figure 2.

Univariate and multivariate analysis of risk factors for mortality was presented in Table 4. In univariate analysis, high plateletcrit [odds ratio $(\mathrm{OR})=2.88,95 \%$ confidence interval $(\mathrm{Cl})$ : 2.08-3.98, $p<0.001$ ], age $(\mathrm{OR}=1.07,95 \% \mathrm{Cl}: 1.06-1.08, \mathrm{p}<0.001)$, DM (OR $=1.83,95 \% \mathrm{Cl}: 1.32-2.53, \mathrm{p}<0.001), \mathrm{CKD}(\mathrm{OR}=1.91,95 \%$ Cl: 1.36-2.67, $\mathrm{p}<0.001$ ), Killip score $(\mathrm{OR}=1.67,95 \% \mathrm{Cl}$ : 1.15 - 
Table 1. Clinical and laboratory characteristics of patients with STEMI divided into 3 groups according to plateletcrit

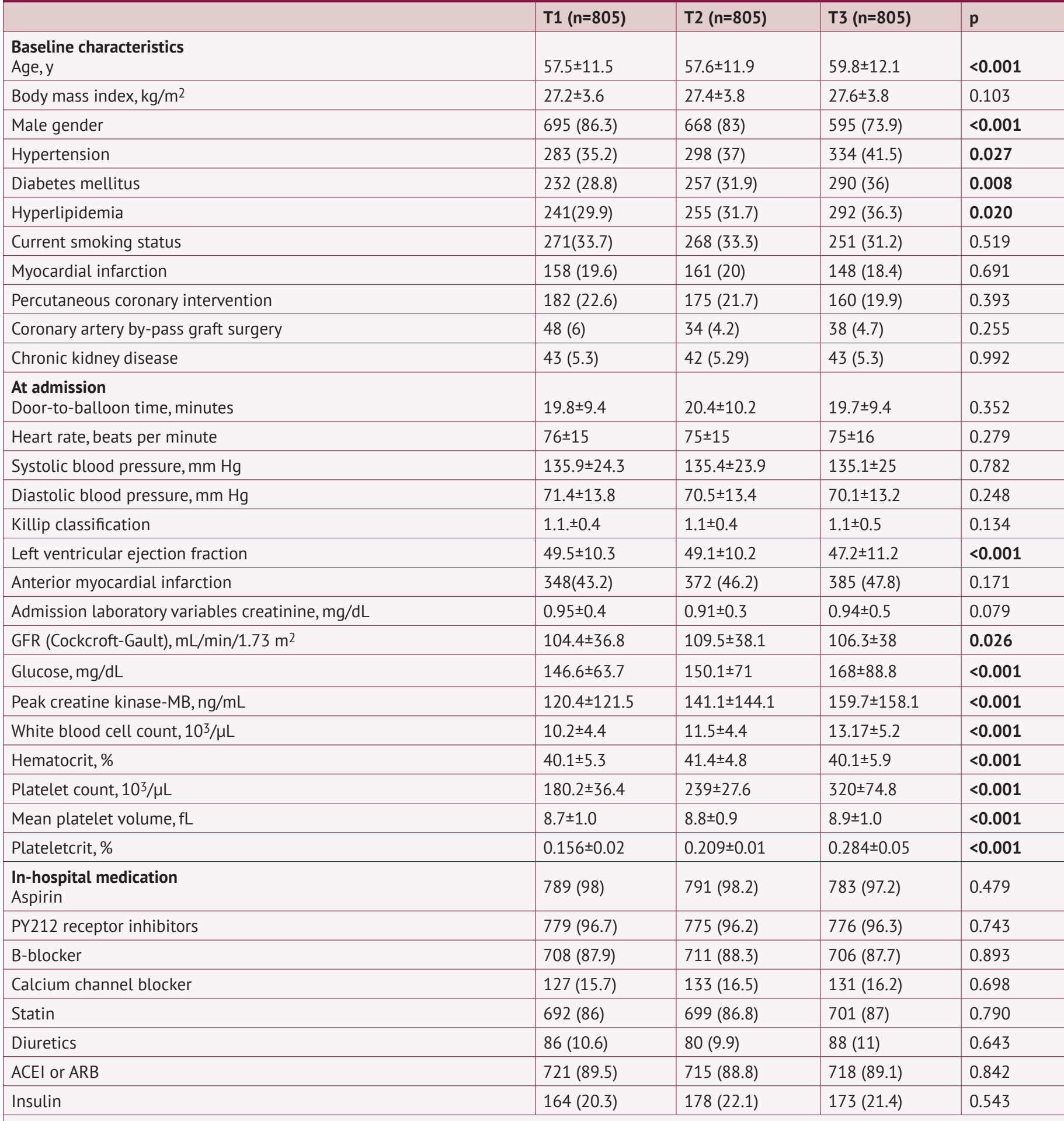

GFR: Glomerular filtration rate, ACEI: Angiotensin converting enzyme inhibitor, ARB: Angiotensin receptor blocker, STEMI: Segment elevation myocardial infarction

2.38, $\mathrm{p}=0.002)$, LVEF (OR $=0.95,95 \% \mathrm{Cl}: 0.93-0.97, \mathrm{p}<0.001)$, peak CK-MB (OR $=1.00,95 \% \mathrm{Cl}: 1.00-1.00, \mathrm{p}<0.001)$, and white blood cell count $(\mathrm{OR}=1.29,95 \% \mathrm{Cl}: 1.09-1.62, \mathrm{p}=0.002)$ were found to be the predictors of mortality.
In the multivariable regression analysis, using a model adjusted for the aforementioned parameters, high plateletcrit $(\mathrm{OR}=2.41,95 \% \mathrm{Cl}: 2.12-2.70, \mathrm{p}<0.001)$, age $(\mathrm{OR}=1.06,95 \% \mathrm{Cl}$ : $1.05-1.07, p<0.001)$, $D M(O R=1.54,95 \% \mathrm{Cl}: 0.98-2.16, p=0.013)$, 
CKD (OR =1.78, 95\% Cl: 1.14-2.44, $p=0.002)$, Killip score (OR $=1.42$, 95\% Cl: 1.06-2.81, $p=0.025)$, LVEF (OR $=0.93,95 \% \mathrm{Cl}$ : 0.91-0.95, $p<0.001$ ), and peak CK-MB (OR =1.00, 95\% Cl: $1.00-$ $1.00, p<0.003)$ were found to be independent predictors for mortality.

\section{Discussion}

The study showed higher in-hospital and long-term mortality among the patients with higher PCT values in STEMI. PCT was found to be an independent predictor for mortality in this

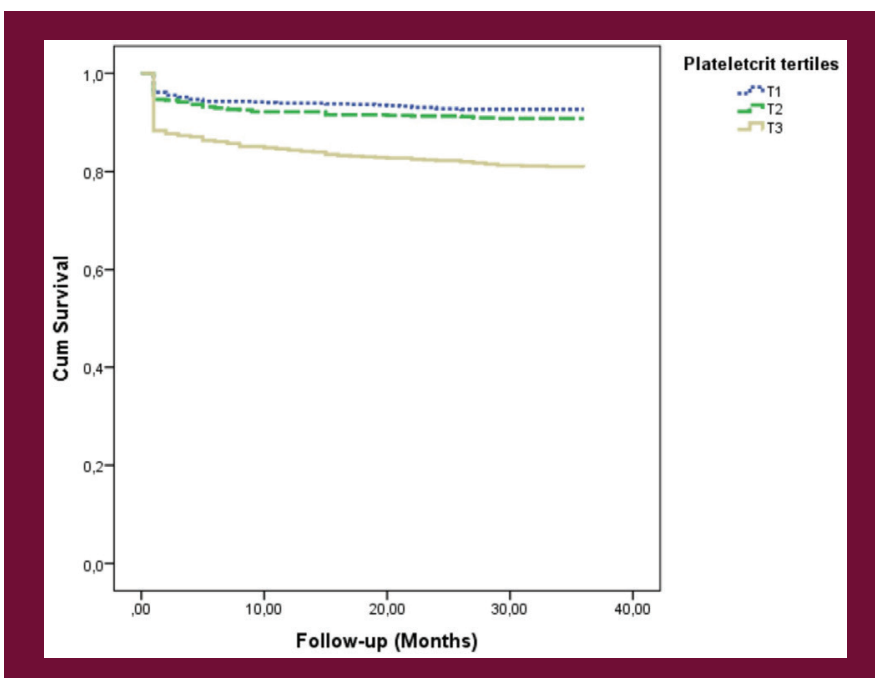

Figure 2. Kaplan-Meier survival curve setting besides age, DM, CKD, Killip score, left ventricle ejection fraction and peak CK-MB.

Larger platelets are biologically more active and powerful than the smaller one with regard to pro-thrombotic properties. MPV was found to show a high specificity and predictive value for coronary slow flow, stable ischemic heart diseases, and ACSs $(13,14,15)$. Both MPV and PCT were found to be higher in saphenous vein graft disease after by-pass surgery (16) and were found to be associated with short-term outcomes of ischemic stroke (17). Moreover, PCT was related to increased venous thromboembolism risk in females (18). Impact of PCT was studied in high thrombus burden clinical scenario in two separate studies $(8,9)$. Cetin et al. (9) observed higher PDW and PCT values in young STEMI patients than in the older ones, which is reasoned with platelet activity in the young ones. On the other hand, Ugur et al. (8) showed increased long-term mortality in STEMI patients with higher PCT values. Despite the fact that patients with higher PCT showed more in-hospital shock, inotrope use and lower ejection fraction, there were no statistically significant difference in relation of in-hospital mortality (8). We showed increased acute kidney injury, target lesion revascularization, stent thrombosis, cardiogenic shock and in-hospital mortality among the patients with higher PCT values besides increased long term mortality.

The fourth universal definition of $\mathrm{MI}$ guideline defines type $1 \mathrm{MI}$ as having an occlusive or non-occlusive intravascular thrombosis secondary to atherosclerotic plaque disruption

Table 2. Angiographic analysis of patients with STEMI divided into 3 groups according to plateletcrit

\begin{tabular}{|c|c|c|c|c|}
\hline & T1 $(n=805)$ & T2 (n=805) & T3 $(n=805)$ & $\mathrm{p}$ \\
\hline $\begin{array}{l}\text { Vessel stenosis (>50\%) } \\
1 \text { vessel }\end{array}$ & $446(55.4)$ & $423(52.5)$ & $436(54.1)$ & 0.327 \\
\hline 2 vessels & $208(25.8)$ & $222(27.6)$ & $223(27.7)$ & 0.523 \\
\hline 3 vessels & $151(18.8)$ & $160(19.9)$ & $146(18.1)$ & 0.751 \\
\hline $\begin{array}{l}\text { Intervention type } \\
\text { Direct stenting }\end{array}$ & $31(3.8)$ & $33(4)$ & $31(3.8)$ & 0.971 \\
\hline PTCA and stenting & $651(80.8)$ & $644(80)$ & 655 (81.39) & 0.893 \\
\hline Only PTCA & $123(15.2)$ & $128(15.9)$ & $119(14.7)$ & 0.815 \\
\hline $\begin{array}{l}\text { Stent type } \\
\text { Drug eluting stent }\end{array}$ & $587(87.3)$ & $577(85.2)$ & $589(85.8)$ & 0.279 \\
\hline Bare metal stent & $85(12.6)$ & $100(14.7)$ & 97 (14.1) & 0.311 \\
\hline $\begin{array}{l}\text { TIMI blood flow after intervention } \\
\text { TIMI } 0\end{array}$ & $38(4.7)$ & $54(6.7)$ & $50(6.2)$ & 0.161 \\
\hline TIMI1 & $13(1.6)$ & $12(1.5)$ & $23(2.9)$ & 0.235 \\
\hline TIMI 2 & $44(5.5)$ & $39(4.8)$ & $49(6.1)$ & 0.125 \\
\hline TIMI 3 & $710(88.2)$ & $700(87)$ & $683(85.8)$ & 0.269 \\
\hline No-reflow phenomenon & $95(11.8)$ & $105(13)$ & $122(15.2)$ & 0.135 \\
\hline
\end{tabular}


(rupture or erosion) (19). An increased pro-inflammatory and pro-thrombotic activity with unbalanced stress may cause a plaque rupture, subsequent thrombosis formation, and complete occlusion. A vicious circle between increased thrombosis and inflammation is further aggravated with increased release of pro-inflammatory cytokines. Megakaryocyte proliferation is promoted with interleukin (IL)-1, IL-3, and IL-6 that increases circulating platelet count with larger and reactive ones $(20,21)$. Increased platelet mass (PCT) may show higher pro-thrombotic and pro-inflammatory activity which could be associated with worse outcomes in STEMI setting. It is already showed that patients with heavy thrombus burden suffer more in-hospital and long-term mortality than the others in STEMI (22).

\section{Study Limitations}

This study had several limitations. It is a single-center, retrospective study without randomization and thus subject to selection bias; however, consecutive patients were selected to lessen possible effects of this limitation. In addition, inflammatory markers such as high-sensitive C-reactive protein, B-type natriuretic peptide, other proinflammatory cytokines, and markers of oxidative stress were not analyzed. Despite adjusting for multiple risk factors, it is possible that there might have been residual confounding conditions and medications.

\section{Conclusion}

This is the first study to show high in-hospital and long-term mortality of STEMI patients with high PCT values at admission.

Table 3. In-hospital and long-term outcomes of patients with STEMI divided into 3 groups according to plateletcrit levels

\begin{tabular}{|l|l|l|l|l|}
\hline & T1 & T2 & T3 & p \\
\hline $\begin{array}{l}\text { In-hospital outcomes } \\
\text { Acute kidney injury }\end{array}$ & $89(11.1)$ & $96(11.9)$ & $123(15.3)$ & 0.027 \\
\hline Recurrent myocardial infarction & $17(2.1)$ & $29(3.6)$ & $62(7.7)$ & $<0.001$ \\
\hline Target lesion revascularization & $28(3.5)$ & $38(4.7)$ & $60(7.5)$ & 0.001 \\
\hline Stent thrombosis & $15(1.9)$ & $28(3.5)$ & $40(5.0)$ & 0.003 \\
\hline Cardiogenic shock & $26(3.2)$ & $35(4.3)$ & $65(8.1)$ & $<0.001$ \\
\hline All-cause mortality & $30(3.7)$ & $39(4.8)$ & $92(11.4)$ & $<0.001$ \\
\hline $\begin{array}{l}\text { Out-hospital course } \\
\text { Follow-up time (months) }\end{array}$ & $33.7 \pm 8.2$ & $33.1 \pm 9.1$ & $30.2 \pm 12.4$ & $<0.001$ \\
\hline All-cause mortality & $29(3.7)$ & $35(4.6)$ & $62(8.7)$ & $<0.001$ \\
\hline
\end{tabular}

Table 4. Univariate analysis and multivariate model for in-hospital mortality

\begin{tabular}{|l|l|l|l|l|l|}
\hline Univariate analysis & $\mathbf{p}$ & OR (95\% Cl) & Multivariate analysis & $\mathbf{p}$ & OR (95\% CI) \\
\hline High plateletcrit & $<0.001$ & $2.88(2.08-3.98)$ & High plateletcrit & $<0.001$ & $2.41(2.12-2.70)$ \\
\hline Age & $<0.001$ & $1.07(1.06-1.08)$ & Age & $<0.001$ & $1.06(1.05-1.07)$ \\
\hline Male gender & 0.077 & $1.40(0.96-2.04)$ & & & \\
\hline Body mass index & 0.274 & $0.97(0.93-1.01)$ & & & \\
\hline Hypertension & 0.065 & $1.35(0.98-1.86)$ & & & \\
\hline Diabetes mellitus & $<0.001$ & $1.83(1.32-2.53)$ & Diabetes Mellitus & 0.013 & $1.54(0.98-2.16)$ \\
\hline Hyperlipidemia & 0.015 & $1.50(1.08-2.08)$ & & & \\
\hline Smoking & 0.685 & $1.07(0.76-1.50)$ & & & \\
\hline Chronic kidney disease & $<0.001$ & $1.91(1.36-2.67)$ & Chronic kidney disease & 0.002 & $1.78(1.14-2.44)$ \\
\hline Previous myocardial infarction & 0.004 & $1.64(1.14-2.45)$ & & & \\
\hline Killip score & 0.002 & $1.67(1.15-2.38)$ & Killip score & 0.025 & $1.42(1.06-2.81)$ \\
\hline Anterior myocardial infarction & 0.008 & $1.60(1.12-2.67)$ & & & \\
\hline Left ventricular ejection fraction & $<0.001$ & $0.95(0.93-0.97)$ & Left ventricular ejection fraction & $<0.001$ & $0.93(0.91-0.95)$ \\
\hline Peak creatine kinase-MB & $<0.001$ & $1.00(1.00-1.00)$ & Peak creatine kinase-MB & 0.003 & $1.00(1.00-1.00)$ \\
\hline White blood cell count & 0.002 & $1.29(1.09-1.62)$ & & & \\
\hline Hematocrit & 0.308 & $0.98(0.82-1.16)$ & & & \\
\hline OR: Odds ratio, Cl: Confidence interval, MB: Myocardial band & & & & \\
\hline
\end{tabular}


High PCT was found as an independent risk factor for both inhospital and long-term cardiovascular mortality age, DM, CKD, Killip score, left ventricle ejection fraction and peak CK-MB.

\section{Ethics}

Ethics Committee Approval: The study was approved by the local ethics committee (28.08.2020, 20/312).

Informed Consent: Due to the retrospective nature, there was no opportunity to obtain written informed consent from the patients.

Peer-review: Externally and internally peer-reviewed.

\section{Authorship Contributions}

Surgical and Medical Practices: M.K., A.K., G.I., O.B., S.D., Concept: M.K., A.K., G.I., O.B., S.D., Design: M.K., A.K., G.I., O.B., S.D., F.Ö., A.L.O., Data Collection or Processing: M.K., A.K., G.I., O.B., S.D., Analysis or Interpretation: M.K., A.K., G.I., O.B., S.D., Literature Search: M.K., A.K., G.I., O.B., S.D., F.Ö., Writing: M.K., A.K., G.I.

Conflict of Interest: No conflict of interest was declared by the authors.

Financial Disclosure: The authors declared that this study received no financial support.

\section{References}

1. Garraud O, Cognasse F. Are platelets cells? and if yes, are they immune cells? Front Immunol. 2015;6:70. [Crossref]

2. Maroko PR, Braunwald E. Modification of myocardial infarction size after coronary occlusion. Ann Intern Med. 1973;79:720-733. [Crossref]

3. Bessman JD, Williams $\sqcup$, Gilmer PR Jr. Platelet size in health and hematologic disease. Am J Clin Pathol. 1982;78:150-153. [Crossref]

4. Dogan A, Aksoy F, Icli A, Arslan A, Varol E, Uysal BA, et al. Mean platelet volume is associated with culprit lesion severity and cardiac events in acute coronary syndromes without ST elevation. Blood Coagul Fibrinolysis. 2012;23:324-330. [Crossref]

5. Kostrubiec M, Łabyk A, Pedowska-Włoszek J, Hrynkiewicz-Szyma'nska A, Pacho S, Jankowski K, et al. Mean platelet volume predicts early death in acute pulmonary embolism. Heart. 2010;96:460-465. [Crossref]

6. Akpinar I,Sayin MR, Gursoy YC,Aktop Z, Karabag T, Kucuk E, et al. Plateletcrit and red cell distribution width are independent predictors of the slow coronary flow phenomenon.J Cardiol. 2014;63:112-118. [Crossref]

7. Chu SG, Becker RC, Berger PB, Bhatt DL, Eikelboom JW, Konkle B, et al. Mean platelet volume as a predictor of cardiovascular risk: a systematic review and meta-analysis.J Thromb Haemost. 2010;8:148-156. [Crossref]

8. Ugur M,Ayhan E, Bozbay M, Çiçek G, Ergelen M, Işık T, et al. The independent association of plateletcrit with long-term outcomes in patients undergoing primary percutaneous coronary intervention.J Crit Care. 2014;29:978-981. [Crossref]

9. Cetin MS, Cetin EHO, Akdi A, Aras D, Topaloglu S, Temizhan A, et al. Platelet distribution width and plateletcrit: novel biomarkers of ST elevation myocardial infarction in young patients. Kardiol Pol. 2017;75:1005-1012. [Crossref]

10. Thygesen K,Alpert JS, Jaffe AS, Simoons ML, Chaitman BR, White HD. Third universal definition of myocardial infarction. Circulation. 2012;126:20202035. [Crossref]

11. Cockcroft DW, Gault MH. Prediction of creatinine clearance from serum creatinine. Nephron. 1976;16:31-41. [Crossref]

12. Schiller NB, Shah PM, Crawford M, DeMaria A, Devereux R, Feigenbaum $\mathrm{H}$, et al. Recommendations for quantitation of the left ventricle by twodimensional echocardiography. American Society of Echocardiography Committee on Standards, Subcommittee on Quantitation of TwoDimensional Echocardiograms. J Am Soc Echocardiogr. 1989;2:358-367. [Crossref]

13. Nurkalem Z, Alper AT, Orhan AL, Zencirci AE, Sari I, Erer B, et al. Mean platelet volume in patients with slow coronary flow and its relationship with clinical presentation. Turk Kardiyol Dern Ars. 2008;36:363-367. [Pubmed]

14. Chu SG, Becker RC, Berger PB, Bhatt DL, Eikelboom JW, Konkle B, et al. Mean platelet volume as a predictor of cardiovascular risk: a systematic review and meta-analysis.J Thromb Haemost. 2010;8:148-156. [Crossref]

15. Boos C, Lip GY. Platelet activation and cardiovascular outcomes in acute coronary syndromes.J Thromb Haemost. 2006;4:2542-2543. [Crossref]

16. Akpinar I, Sayin MR, Gursoy YC, Karabag T, Kucuk E, Buyukuysal MC, et al. Plateletcrit: a platelet marker associated with saphenous vein graft disease. Herz. 2014;39:142-148. [Crossref]

17. Mohamed AA, Elnady HM, Alhewaig HK, Hefny HM, Khodery A. The mean platelet volume and plateletcrit as predictors of short-term outcome of acute ischemic stroke. Egypt J Neurol Psychiatr Neurosurg. 2019;55:1-6. [Crossref]

18. Vázquez-Santiago M, Vilalta N,Ziyatdinov A, Cuevas B, Macho R, Pujol-Moix $\mathrm{N}$, et al. Platelet count and plateletcrit are associated with an increased risk of venous thrombosis in females. Results from the RETROVE study. Thromb Res. 2017;157:162-164. [Crossref]

19. Thygesen K, Alpert JS, Jaffe AS, Chaitman BR, Bax JJ, Morrow DA, et al. Fourth universal definition of myocardial infarction. J Am Coll Cardiol. 2018;7:2231-2264. [Crossref]

20. Klinger $\mathrm{MH}$, Jelkmann W. Role of blood platelets in infection and inflammation.J Interferon Cytokine Res. 2002;22:913-922. [Crossref]

21. Alexandrakis MG, Passam FH, Moschandrea IA, Christophoridou AV, Pappa CA, Coulocheri SA, et al. Levels of serum cytokines and acute phase proteins in patients with essential and cancer-related thrombocytosis. Am J Clin Oncol. 2003;26:135-140. [Crossref]

22. Tatlisu MA, Kaya A, Keskin M, Uzman O, Borklu EB, Cinier G, et al. The association of the coronary thrombus burden with all-cause mortality and major cardiac events in ST-segment elevation myocardial infarction patients treated with tirofiban. Coron Artery Dis. 2016;27:543-550. [Crossref] 